Article

\title{
Empowering the People's Truth Through Social Media? (De)Legitimizing Truth Claims of Populist Politicians and Citizens
}

\author{
Michael Hameleers \\ Amsterdam School of Communication Research, University of Amsterdam, The Netherlands; m.hameleers@uva.nl
}

Submitted: 22 July 2021 | Accepted: 8 October 2021 | Published: 17 February 2022

\begin{abstract}
Right-wing populists have allegedly fueled increasing levels of distrust regarding expert knowledge and empirical evidence. Yet, we know little about how right-wing populist politicians and citizens use social media to construct and oppose truth claims. Using a qualitative analysis of Twitter and Facebook posts communicated by right-wing populists and citizens supporting populist ideas in the Netherlands, this article offers in-depth insights into processes of legitimization (confirming truth claims) and de-legitimization (opposing truth claims). The main conclusion is that right-wing populists and citizens supporting populism do not share a universal way of referring to reality. They use social media to communicate a confirmation-biased reality: Expert knowledge and evidence are de-contextualized or reinterpreted and aligned with rightwing populist agendas. References to the people's experiences and worldviews, conspiracy theories and crisis sentiments are used to legitimize people's opposition to expert knowledge and empirical evidence. Based on these findings, we coin the idea of an "adaptable construction of confirmation-biased truth claims" central in right-wing populist interpretations of reality. In times of increasing attacks on expert knowledge and empirical evidence, populist discourse may fuel an antagonism between the ordinary people's experiences and the truth claims of established media channels and politicians in government. Social media offer a platform to members of the public to engage in discussions about (un)truthfulness, perceived deception, and populist oppositions-potentially amplifying divides between the ordinary people's experiences and expert sources.
\end{abstract}

\section{Keywords}

disinformation; fake news; misinformation; populism; right-wing populism; social media; truthfulness

\section{Issue}

This article is part of the issue "Analyzing Citizen Engagement With European Politics Through Social Media" edited by Pieter de Wilde (Norwegian University of Science and Technology), Astrid Rasch (Norwegian University of Science and Technology), and Michael Bossetta (Lund University).

(C) 2022 by the author(s); licensee Cogitatio (Lisbon, Portugal). This article is licensed under a Creative Commons Attribution 4.0 International License (CC BY).

\section{Introduction}

Populist ideas, which revolve around the construction of an antagonistic narrative emphasizing the divide between the "good" ordinary people and the "corrupt" elite (Mudde, 2004), are very prominent on social media. Social media have empowered populist politicians and citizens with populist worldviews to express their viewpoints directly, and to avoid the elite channels of communication they tend to distrust (Engesser et al., 2017). Populism's antagonism has an important, yet largely unexplored epistemic dimension: Right-wing populist
(RWP) ideas oftentimes oppose the reality constructions of established media, political, and scientific institutions (Mede \& Schäfer, 2020) whilst replacing the elite's interpretation of the truth and reality with alternative facts or experiences of ordinary people (Harambam \& Aupers, 2015). Responding to developments toward increasing distrust in the mainstream media, cultivated and amplified by RWP actors (Waisbord, 2018), the mainstream media and scientific actors are increasingly regarded as part of the "corrupt" elite who is not listening to the voice of the people when creating knowledge or when analysing issues (e.g., Mede \& Schäfer, 2020). In this 
setting, this article seeks to answer the question of how social media may empower both political actors and citizens with an affinity for populist worldviews to express their perspective on truth and knowledge in an antagonistic manner (also see e.g., Krämer et al., 2021).

The central concepts we focus on in this article are the legitimization versus de-legitimization of truth claims. We understand the legitimization of truth claims as the arguments and evidence forwarded to justify certain perspectives on reality. The de-legitimization of truth claims can be understood as a rejection or refutation of the truth claims made by opposed actors - a discourse that resonates with the "fake news" accusations voiced by RWP actors (e.g., Egelhofer \& Lecheler, 2019; Waisbord, 2018). Together, the dynamics of legitimization and de-legitimization may contribute to an antagonistic populist reality construction: Claims that are congruent with people's beliefs are justified and defended, whereas opposed claims are rejected or counter-argued. This resonates with the conceptualization of partisanship as a social identity (e.g., West \& lyengar, 2020), which presupposes that people's support for an ideology or political party is internalized as a social identity. In-group favoritism and out-group hostility are central to the construction of such identities, which we extrapolate to the construction of truth claims in online populist discourse. In this context, the truth claims of people's in-group may be seen as honest and accurate, whereas the truth claims expressed by out-groups are seen as dishonest or even deceptive. In this setting, we introduce the following research questions:

RQ1: To what extent and how does populist rhetoric afforded by social media de-legitimize and oppose elite actors whilst introducing counternarratives within the same traditions of authoritative knowledge?

RQ2: To what extent and how is populism expressed via social media opposing the principles of expertbased and empirically founded knowledge?

To answer these research questions, this study relies on a qualitative content analysis of Twitter and Facebook pages in the Netherlands. We focus on the Twitter pages of RWP actors to better understand how discourses of (de)legitimization are constructed by antagonistic political actors who have been associated with hostile attacks on the legitimacy of the media, scientists, and political elites (e.g., Waisbord, 2018). We subsequentially analyse Facebook pages of ordinary citizens who support these populist actors and their ideas. Although populism is thin in the ideology it conveys (Mudde, 2004), we specifically look at right-wing populism in this article because these sentiments and political actors are more prominent in the Dutch context. Here, we rely on an in-depth analysis of 200 posts on each platform to assess how references to the truth are expressed and opposed. With our focus on ordinary citizens as communicators of (de)legitimizing discourses and populism, we aim to better understand how the affordances of social media that promote interaction, political participation, and deliberation empower members of the public to construct antagonistic narratives on reality in a context of growing relativism toward (scientific) facts.

Theoretically, this article aims to make an important contribution to the literature exploring how rightwing populism refers to truth, knowledge, and deception (e.g., Egelhofer \& Lecheler, 2019; Mede \& Schäfer, 2020; Waisbord, 2018). By analysing the social media expressions of both RWP politicians and citizens supporting such worldviews, we illustrate how social media empower both political actors and members of the public to express antagonistic narratives on realityherewith potentially contributing to an amplification of societal divides based on divergent perspectives on the truth. Hence, considering the potential of social media to express confirmation-biased truth claims in the context of social support from like-minded community members, political dialogue may be hampered. This is at odds with the principles of a well-functioning deliberative democracy: If people express one-sided truth claims in homogenous communities without listening to the other side, divergent ideas on what the truth entails may become further apart to the point of epistemic polarization.

\section{Theoretical Framework}

\subsection{Populist Rhetoric and the Construction of (Counter-)knowledge}

Populism stresses an antagonistic divide between the ordinary people and the corrupt elites (e.g., Canovan, 1999; Jagers \& Walgrave, 2007). Populist ideas frame the ordinary people as a relatively deprived in-group, which has a common will that is not represented by the elites. The elites, in turn, are seen as responsible for failing to represent the ordinary people (Hameleers et al., 2017). This ideational core of populism may be expressed to various extents by different (political) actors (Busby et al., 2019). In this article, we aim to understand how this antagonism central to populism relates to the construction of knowledge, truth-claims, and de-legitimizing discourses targeted at the media, experts, and scientists-discourses found to be central in RWPs' construction of (counter-)knowledge (e.g., Krämer et al., 2021; Ylä-Anttila, 2018).

Mede and Schäfer (2020) coined the term "sciencerelated populism" to describe populism's understanding of science. Science-related populism holds that the ordinary people are constructed as a virtuous in-group that is framed in opposition to "evil" scientific elites. The elite's version of reality is deemed illegitimate and (intentionally) misleading, whereas the people are said to be endowed with truth-speaking sovereignty (Mede \& Schäfer, 2020). In line with this notion of populism's 
epistemic antagonism, populist rhetoric is known to de-legitimize scientific consensus and the objectivity of expert knowledge. This allegedly confounded knowledge is replaced with issue-consistent "counter" or "alternative" knowledge (Harambam \& Aupers, 2015; Ylä-Anttila, 2018). Science-related populism includes popular demands for science-related decision-making sovereignty, which means that the people (and not the academic elite) are seen as a legitimate source of scientific decision-making: Their ideas about true knowledge are allegedly not biased by ideological interests or corruption (Mede \& Schäfer, 2020)-which means that they should have the power to formulate truth claims related to science. Krämer et al. (2021) found empirical support for such populist constructions of reality on social media: Users with an affinity for right-wing populism cultivated distrust in established knowledge and, at the same time, emphasized the merits of alternative authorities and evidence. Using a mixed-methods analysis of far-right Twitter networks in Brazil, Oliveira et al. (2021) reveal how users selectively use ideologically aligned sources to substantiate truth claims and conspiracies on Covid-19. Their findings also reveal how far-right leaders and their supporters create a moral discourse in which the "virtuous ordinary people" are pitted against a "corrupt" academic elite-discourses of legitimization and de-legitimization that resonate strongly with the principles of science-related populism (Mede \& Schäfer, 2020).

The question remains how fundamental populism's antagonistic relationship to the established truth actually is. Two positions can be forwarded. First, Harambam and Aupers (2015) suggest that populism does not necessarily oppose scientific institutions and the techniques or modes of truth-seeking used by the established order. Just like populism may not simply be dismissed as undemocratic or a system-level rejection of politics (e.g., Canovan, 1999), populist rhetoric may emphasize that the current elites claiming authority on defining truthfulness and valid empirical evidence are corrupt, and therefore need to be replaced with alternative authorities and counter-knowledge. As an example, many interpretations that framed Covid-19 during the 2020 pandemic as "fake news" or failing policy did not reject the ideas of science and empirical evidence, but emphasized that elite sources had to be replaced by other knowledge sources-such as alternative doctors, health experts, and alternative "unbiased" sources of verified knowledge.

An alternative perspective on populist knowledge systematically rejects scientific techniques. Saurette and Gunster (2011) used the term "epistemological populism" to describe the populist replacement of scientific principles with people-centric evidence and experiences. This perspective implies that, to understand reality, one cannot rely on expert knowledge or empirical evidence: Such accounts are too far-removed from the worlds and experiences of the people-and therefore illegitimate claims of truthfulness. An example of this perspec- tive is the claim emphasized in conspiracies stating that Covid-19 is "nothing but a bad flu" substantiated by arguments that people do not know anyone who actually had this virus, and those that might have had it, experienced only the symptoms of a normal flu. Common sense, then, is used to substantiate the alternative interpretation that we do not really face a threat.

In the context of these two perspectives, this article explores how populist politicians and citizens supporting populist ideas express truth claims. Here, we specifically focus on how truth claims are constructed to (de)legitimize a congruent narrative. Legitimization is understood here as the different ways in which evidence and arguments are used to substantiate and justify an identity-congruent perspective on reality. De-legitimization, in contrast, refers to the rhetoric used to oppose the positions and statements of other parties or out-groups. This understanding of legitimization and de-legitimization aligns with partisanship as a social identity (see e.g., West \& Iyengar, 2020). Truth claims of the in-group are legitimized, whereas the truth claims from out-groups are de-legitimized. This is also supported by the findings of Oliveira et al. (2021), who found that discourses of far-right leaders and their followers revolved around the legitimization of scientists' knowledge sources that supported their ideological values, and the de-legitimization of opposed evidence and expert knowledge.

\subsection{Populist Constructions of Truth and Knowledge on Social Media}

Social media platforms may amplify populist rhetoric as they allow for the circumvention of elite actors whilst directly addressing the ordinary people (Engesser et al., 2017). The technological possibilities of social media and populist ideas thus align: Online platforms can enable the circumvention of elite actors whilst also allowing political actors to signal closeness to the people by using the same channels and styles of communication as members of the public. The affinity between populism and social media can also be understood as the possibilities of direct representation offered by social media (Gerbaudo, 2018): Social media give a voice to people and politicians who claim to be underrepresented and silenced by the established order.

Similar to Gerbaudo's (2018) analysis of an affinity between social media and populist expressions, Hopster (2021) distinguishes four affordances of social media that enable populist communication. Here, affordances can be understood as the ways in which the technological setting of social media offers the opportunity for people to behave in specific ways (e.g., Bucher \& Helmond, 2018). Applying this perspective, Hopster (2021) argues that four affordances in particular may explain the affinity between social media and populism: (a) the ability to circumvent journalistic gatekeepers and editorial filters (also see Engesser et al., 2017); (b) the 
algorithmic amplification of dramatized and sensational claims; (c) the option to use populist communication styles, such as simplistic and emotional language; and (d) the ability to express and monitor the people's general will in real time. Extrapolating these affordances to the populist construction of knowledge and reality, especially the option to circumvent journalistic gatekeepers and the ability to directly refer to and represent the people's voice and experiences are relevant to consider. Using social media platforms, populist leaders and citizens with populist worldviews can create and disseminate truth claims based on the ordinary people's experiences and common sense, sidestepping the analyses and expert sources they distrust and oppose (e.g., Fawzi, 2019; Waisbord, 2018). Social media may thus offer supportive channels for the alternative truth claims and knowledge constructions central in populist discourse: These alternative and antagonistic constructions of reality can be disseminated to members of the public via unfiltered channels, and the absence of gatekeepers means that the hostile attacks on "fake news" media, scientists, and experts can reach the ordinary people directly.

Next to these affordances, social media may offer a context for people to seek out evidence and truth claims that confirm their existing views on the truth (Waisbord, 2018). Although we can assume that not all citizens are trapped in online filter bubbles, RWP supporters in particular are likely to seek shelter in likeminded online communities: They tend to perceive the mainstream media as an "enemy of the people" (Fawzi, 2019), experience belonging to an in-group of deprived ordinary citizens that is allegedly not represented by the established order, and prefer alternative (online) information platforms that confirm their prior anti-establishment views. The high levels of distrust in the mainstream media and political institutions experienced by RWP supporters may explain their attraction to online media platforms that function as "imagined" communities for their populist discontent (Hameleers, 2020).

\section{Research Design}

\subsection{Research focus and Questions}

The specific nature of (right-wing) populist constructions of antagonistic truth claims lies at the heart of this article. Reasoned from the perspective that social media offer an ungated platform that empowers politicians and citizens to define, legitimize, and de-legitimize (opposed) truth claims, we seek to advance our understanding of the epistemic dimensions of online populist communication. To recap, we raise the following research questions to map the discursive construction of truth and un-truths in populists' social media discourse:

RQ1: To what extent and how does populist rhetoric afforded by social media de-legitimize and oppose elite actors whilst introducing counternarratives within the same traditions of authoritative knowledge?

RQ2: To what extent and how is populism expressed via social media opposing the principles of expertbased and empirically founded knowledge?

\subsection{Context and National Setting}

These two questions are answered in the context of the social media expressions of RWP politicians and citizens in the Netherlands: a country with a multiparty system in which right-wing populism has been electorally successful for multiple decades (e.g., Aalberg et al., 2017). In this country, we specifically look at the Twitter communication of two prototypical RWP politicians: Geert Wilders from the Dutch Freedom Party and Thierry Baudet from the RWP party Forum for Democracy (Rooduijn et al., 2019). We contrast these actors' political communication to the populist ideas expressed by supporters of these parties on Facebook community pages that revolve around RWP support. We selected 50 posts of each sub-group (two Facebook and two Twitter profiles), which means that the qualitative findings are not directly generalizable to all populist leaders or citizens with populist attitudes. It thus remains an empirical question how well the findings travel to other settings, although we believe that the general logic distinguishing between the legitimization and de-legitimization of truth claims is relevant across the globe.

\section{Methods}

We used Twitter's API to scrape relevant Tweets posted by the two political actors in the Netherlands. As most (political) communication revolved around the Covid-19 pandemic from March 2020 onward, we decided to use a more diverse sample of Tweets in the period before the pandemic in the Netherlands and compare this period with a sample of Tweets posted in the midst of the pandemic. To this end, we collected an initial sample of 50 Tweets of both politicians in the pre- and post-Covid-19 period $(N=200)$. To make sure that the two sample frames are equal in size, we use a six-months period before the salience of Covid-19 in the political and media debate (July 2019-December 2019) and contrast this to a similar time-period after the crisis erupted (March 2020-August 2020). To avoid a selection bias in the initial sample of Tweets, we randomly selected 50 Tweets for all cells of the sample frame. In line with the principles of the Grounded Theory approach (e.g., Glaser \& Strauss, 1967), the initial sample was first fully analysed before collecting new data. As saturation was achieved (i.e., the in-depth analyses of the additional Tweets did not uncover additional variety in the established themes and categories), we did not oversample Tweets after this additional round of data collection. 
A similar approach was taken for the Facebook pages of citizens supporting the two politicians and their populist ideology: We focus on the same time periods and use the same sample size (50 posts in each cell). We decided to focus on Facebook for citizens' populist discourse as this platform is more likely to be used by citizens with populist attitudes than Twitter (a more unidirectional platform for elite communication, also see e.g., Valenzuela et al., 2018). Hence, citizens with populist attitudes are found to rely more on Facebook for their political information needs (Groshek \& Koc-Michalska, 2017; Schulz et al., 2020), whereas Facebook and Twitter are both associated with the populist communication of political actors. In the context of this study, the Netherlands, Twitter is the most likely channel to be used by populist politicians (e.g., Jacobs \& Spierings, 2019). On Facebook community pages, we analysed how citizens supporting the populist leaders constructed truth claims in terms of legitimizing a reality supporting their in-group as well as opposing the truth claims of out-groups they did not identify with (i.e., elite actors in media and politics). Although Twitter affords one-directional communication, ordinary citizens themselves are more likely to express their views on Facebook community pages. As we were interested in how members of the public are empowered to construct truth claims and antagonistic narratives via social media in the context of right-wing populism, we focus on Facebook pages that offer a forum or "imagined community" for people supporting populist actors and ideas. As saturation check, and to explore the exhaustiveness of our themes, we additionally looked at reactions to Twitter posts and additional timeframes. We herewith avoided a platform bias in our findings. The additional analyses that looked at direct responses to the Twitter posts by the two politicians confirmed the findings found in the Facebook posts. Yet, there was less richness in the Twitter comments, and the themes mainly reflected a simple agreement with the truth claims of the RWP actors in our sample.

\subsection{Analyses}

The tweets were analysed based on a combination of discourse analysis (e.g., Van Dijk, 1993) and the coding steps of the Grounded Theory approach. Sensitizing concepts-analytical categories that gave direction to the labelling and coding of relevant segments of datawere based on theoretical definitions of misinformation (e.g., Vraga \& Bode, 2020) and truth claims (Brewer, 2011). More specifically, within (de)legitimizing discourses, we selectively coded segments of Tweets that referred to any type of (expert) knowledge, evidence or other (relative) constructions of truths and untruths. All relevant segments were arced and coded further using the software package Atlas.ti. With this tool, we subsequentially applied open, selective (focused) and axial coding steps. These coding steps were doc- umented in Atlas.ti. During open coding, all relevant segments of the data were described and labeled in an open-ended way (i.e., fake news accusations targeted at mainstream media channels). During the second step of focused coding, lists of unique open codes were merged, grouped and detached from their context (i.e., de-legitimizing labels to attack the mainstream media). Finally, during axial coding, linkages between the higher-order themes and categories were identified. Peer debriefing was used as a validation and reliability check suited for the nature of the interpretative analyses and qualitative data: A second independent coder followed and checked all data reduction steps and independently used the open codes to construct themesdiscrepancies between researchers were assessed until complete agreement was reached.

\section{Results of the Analysis of Right-Wing Populist Politicians' Tweets}

\subsection{Right-Wing Populists' De-Legitimization of Established Knowledge and Evidence}

The populist divide between the ordinary people and the corrupt elite oftentimes included an attack on the legitimacy and honesty of the elites. Explicit references to "fake news" and "Iying media" were frequently expressed by both leaders, and especially used to de-legitimize issue positions or political actors incongruent with RWP agendas. The context of these labels thus mattered: They were strategically placed to attack positions, expert sources, and evidence when facts were inconvenient, and incongruent with radical RWP ideas (i.e., climate change, pro-immigration positions).

Wilders explicitly attacked the Prime Minister for deceiving the Dutch people. Tweets oftentimes contained a visual or meme depicting the Prime Minister with the label "liar" or showing a long nose to illustrate deception. The media were also attacked and accused of lying to the public. The de-legitimization of the press was mostly addressed to the public broadcaster: "Can we lynch the NOS [public broadcaster] and the rest of the lying media? It will be my pleasure to terminate the public broadcasters." Wilders also expressed the advice to not watch programs of the public broadcaster, as they were allegedly filled with political correctness and self-hatred, which was deemed dishonest. Although Wilders oftentimes voiced an explicit attack on the mainstream media (the public broadcaster) and the established political order (the Prime Minister or elite actors in government) for intentionally deceiving or lying to the people, he did not explicitly de-legitimize evidence or expert knowledge.

The explicit de-legitimization of elitist interpretations was much more salient in the discourse of Thierry Baudet. Just like Wilders, mainstream media and public broadcasters were accused of spreading "fake news." However, moving beyond this de-legitimizing label, Baudet blamed 
platforms, such as YouTube, for worrisome levels of censorship: "Unbelievable that YouTube banned philosopher Stefan Molyneux without any warning and without any clear reason. The censorship starts to take on extremely worrisome proportions." Baudet directed his de-legitimizing attack to platforms and sources that allegedly censored critique or propagated the (dishonest) views of the established order. He also raised a sense of urgency and fearmongering by referring to impediments on the freedom of speech and safety caused by the elitist press: "Criticism on the elites is apparently not allowed. Who of us is still safe and free? What discussions can we still hold? This has to stop!" Next to the media and platforms, Baudet targeted experts and scientists allegedly part of the "dishonest" elite in his populist anti-establishment rhetoric. He even accused universities of actively pushing activist or radical political agendas: "The politicization of the experts. A real problem. Universities with an activist agenda, who are pushing radical ideas and circumventing alternative voices whilst sailing under the flag of 'science' or 'neutral' expertise." Answering RQ1, Wilders did not oppose principles of scientific or expert-based truths and evidence, but explicitly blamed mainstream media and established politicians for deceiving and lying to the people. Baudet's critique went further, and entailed an explicit accusation of a misleading (radical) political bias and censorship allegedly used strategically to silence the people and maintain power discrepancies. This connects to demands for science-related decision-making by the ordinary people: Unlike the alleged biased and corrupt scientific elite, the ordinary people allegedly have no interest in distorting the truth, which also means that they should have the power to make scientific claims.

\subsection{Right-Wing Populist Counternarratives}

Especially in the period surrounding the Covid-19 pandemic, Baudet referred to alternative experts, doctors, and scientists who shared his view on reality and confirmed his anti-establishment views. He, for example, legitimized his opposition to Covid-19 measures by quoting a professor arguing how vaccines are toxic, and included a (de-contextualized) interpretation that confirmed his anti-establishment perspective on Covid-19: "What if he is right, indicating that thousands of people died lonely and too soon whilst our economy is destroyed without a proper cause?" Political elites were also attacked for "hiding" behind alleged "unscientific nonsense." These findings illustrate how scientific discourse was invalidated.

Applied to other issues, such as climate change, scientific evidence was not only de-legitimized, but also contrasted with "common sense" as the real source of truthfulness: "The European Green Deal will cost us way too much - which is the only reality there is. This is conflicting with common sense. It is time to put the Netherlands and our people first." In his discourse, Baudet also labelled the Covid-19 pandemic as "hysterical" - and contrasted the alleged fake reality deliberately staged by the established order with the need to go back to normal life: "Everything needs to re-open again as we are used to. This shows the hypocrisy of power. They do not even believe in the pandemic themselves. All covid-hysterical nonsense is nothing but a big play." Baudet presented his truth claims, which denied Covid-19 as a pandemic and framed it as a normal flu, as the only reality. He referred to his party as the only party that dared to speak the truth: "Can you imagine if FvD will become the biggest party? The only party in Europe who speaks the truth about the virus formerly known as the flu."

Although both Wilders and Baudet clearly and explicitly attacked political elites and mainstream media for being dishonest and for lying to the people (disinformation accusations) whilst de-legitimizing established truths (RQ1), these RWP leaders still referred to and quoted expert knowledge and scientific evidence to confirm their political agendas. This supports findings by Suldovsky et al. (2019) of a selective and ideologically biased labelling of scientific authority, as well as Oliveira et al.'s (2021) conclusions indicating that radical-right wing actors strategically use ideologically aligned sources to substantiate congruent truth claims on social media.

Wilders did not present explicit counter-factual narratives that opposed established truths (RQ2). His populist ideas included attacks on the mainstream media and dishonest elites, but alternative truth claims were absent. This was different for Baudet, who quoted expert knowledge from "alternative" scientists and sources of evidence when these analyses fitted his interpretations. In other cases, the de-legitimization of established truths on Covid-19 was contrasted to references to common sense, the people's knowledge, and a universal anti-establishment reality (RQ2). The de-legitimization of expert knowledge, media sources, and elites as well as the legitimization of alternative narratives followed a clear confirmation bias. These narratives were often present together. This analysis shows that-in terms of making truth claims and de-legitimizing opposed truth claims - a prototypical manner of RWP communication does not exist: Different political leaders use different ways of constructing a confirmation-biased truth and de-legitimize the established order in different ways. The rhetoric they use to refer to deception and truth is adaptable to the context, and confirms their political positions whilst responding to their targeted audience of disenchanted citizens. Discourses of (de)legitimization are strategically employed to avoid cognitive bias (i.e., to fight off attacks from opponents) and maximize electoral gain (i.e., responding to the fears and beliefs of disenchanted voters). The online context empowers them to oppose elites and express hostile discourse without the intervention of gatekeepers. The question remains how citizens supporting these political actors and their ideas use social media to express truth claims in an antagonistic manner. 


\section{Results of the Analysis of Citizens' Facebook Posts}

\subsection{Uncivil Interactions and Fearmongering: Citizens' De-Legitimizing Discourse Online}

RWP supporters used the online space to voice hostile attacks on the established media and verified facts. Here, more than the radical right-wing leaders, RWP supporters emphasized a conspiracy between the elites who allegedly deceived the people to wield power: "Police, politics, judges, media, amusement, culture, education, science, churches: all institutions are governed by a diabolical elite." Especially in the context of the pandemic, RWP supporters voiced distrust in the established version of reality, and actively denied the existence of Covid-19: "Those who believe in the dangerous 'virus narrative' and those who actually see the truth that laws are being removed to let a dictatorship enter can be separated." As this quote illustrates, the epistemic antagonism was even acknowledged by RWP supporters themselves: The people believing in the virus were seen as wrong and part of a conspiracist elite, whereas the in-group of RWP supporters were seen as "awake" and knowledgeable about true facts.

Different from the political leaders, RWP supporters did not frequently blame the mainstream media, although they accused opposed news messages and channels of demonstrating a dishonest left-wing bias. More consistently, RWP supporters pointed to the lies and conspiracies propagated by the elites: "These filthy traitors are amongst us. They are all like Judas: They are betraying the Dutch people." RWP supporters pointed to an elitist enemy-referred to as specific politicians (i.e., the Prime Minister), the government, or simply a general outgroup ("they"). RWP supporters used hostile language that frequently incited and legitimized violence ("we should buy weapons to protect ourselves from these scumbags"). They also expressed death threats targeted at the Prime Minister or other prominent politicians. Applied to the pandemic, the established truths were delegitimized by referring to conspiracies and deception: "They were dishonest when saying how busy they were with intensive care units. If you don't understand that you are deceived by now, you can move to the moon!" More specifically, and applied to the Covid-19 conspiracies expressed by RWP supporters, a strong sense of urgency, fear-mongering, and dystopic consequences were connected to the alleged lies of the elites: "This is nothing but a genocide or de-population program. They do this intentionally. It will get worse, and the deaths caused by the so-called vaccine will not even be associated with the vaccine anymore." In online interactions, people pointed to the severe consequences of the elite conspiracies: "I do not want to frighten you, Betty. But people need to do research and should not think that this is just a shot. It is over soon, and this is wrong. People are dying." These populist constructions of truth claims included an important moral component: The ordinary people and their everyday experiences were seen as virtuous, whereas experts, scientists, and doctors were seen as dishonest, deceptive, and evil: Scientific expertise was rejected and framed as deliberately misleading, allegedly to silence the ordinary people and hiding real threats.

\subsection{Counter-Factual Narratives and Alternative Truth Claims}

Looking at RQ1, RWP supporters, at times, used the same rhetorical tools as the established order to substantiate their own truth claims: Scientific evidence and experts were used to prove that the corrupt elite was lying to the people: "Using research and experts from India, and other papers, we show that hydroxychloroquine works. But others use fake evidence just to show it does not work." People aimed to demonstrate that they knew the "real" facts that they could see behind the "smoke screen" enforced by the elites:

There are scientists and virologists who expect that vaccinated people will suffer from a new virus that comes soon. I am not even talking about longer-term consequences. The people who are already vaccinated are used as lab rats. I know exactly what is going on here.

Despite referring to alternative facts and evidence, expert knowledge and empirical evidence were not clearly contextualized or substantiated with sources (i.e., doctors or a majority of experts were referred to, without explaining the affiliation and expertise of the source, or the context of research findings).

Responding to RQ1 and RQ2, RWP supporters pointed to an alternative reality framed in opposition to the alleged lies and conspiracies of the elites. This reality was supported by mentioning alternative sources of expert knowledge and empirical evidence-although these were used instrumentally to substantiate truth claims without offering a context or argument for the relevance of expert knowledge. Next to truth claims based on expert knowledge and evidence, common sense and references to an elitist conspiracy were used as arguments to substantiate anti-establishment truth claims. RWP supporters claimed legitimacy for an alternative reality by revealing the "hidden" truths and conspiracies that were severely threatening the ordinary people's lives: "Let's not call it a vaccine, but genetic manipulation and genocide." The RWP discourse analysed does not simply reject expert knowledge and empirical evidence (RQ2), but constructs a counter-factual narrative that uses a mixture of de-legitimizing attacks on expert knowledge and elite actors, confirmation-biased evidence and expert knowledge, and a strong emphasis on the dystopian consequences of elite conspiracies and an urgency to reveal the hidden truth.

The additional analysis of responses to the Tweets of both political leaders confirmed the themes discussed 
here. Although the comments of the ordinary people (and trolls) mainly expressed agreement with the viewpoints of the politicians, they also, at times, gave room for interaction between members of the ordinary people. Some people challenged each other, or asked others to clarify why they made certain statements. Yet, the findings demonstrate that, just like the Facebook community pages, responses to the discourse of RWP political actors on Twitters consolidate a confirmation-biased reality in which the antagonism between virtuous ordinary people and the deception of elite actors is central.

\section{Conclusions}

Using a qualitative content analysis of the social media expressions of RWP leaders and supporters, we asked how RWPs use the technological affordances of social media-most notably the options to circumvent elite gatekeepers and directly speak to the ordinary people and their concerns-to de-legitimize established expertise, truth claims, and evidence whilst legitimizing a people-centric version of the truth. We found that the two radical RWPs in the Dutch Twitter landscape-Baudet and Wilders-frequently accused the established media of spreading fake news and lying to the ordinary people. This confirms earlier research on the centrality of media critique and fake news accusations in RWP rhetoric (e.g., Egelhofer \& Lecheler, 2019; Hameleers \& Minihold, 2021; Waisbord, 2018). This theme overlaps with the interpretation of RWP supporters, who also perceived the mainstream media as an enemy of the people (also see Fawzi, 2019). Yet, this theme was far less salient among RWP supporters than politicians: Supporters more generally referred to an unspecified or general enemy (i.e., they, the elites, politicians) and used more hostile rhetoric to exclude the established order from the people.

In line with literature signaling anti-social and detrimental consequences of online deliberation (Lowry et al., 2016), our findings indicate that online spaces are used to express hostile sentiments toward the elites, often in the forms of swearing, violence, death threats, and hate speech. Next to the more hostile tone of citizens' compared to politicians' discourse, the social media users went further in pointing to conspiracies with dystopian consequences, especially in light of Covid-19. The RWP supporters referred to the ordinary people as the only ones able to see the painful reality that is deliberately hidden from the public. The corrupt elites were seen as caught up in a conspiracy, aiming for genocide, total dominance and control over the population, or even genetic modification: Covid-19 was seen as a façade to hide reality and legitimize alleged "lethal weapons." The social media users emphasized a strong sense of urgency and fear for the future: They expressed a need for mobilization and urgent action against the elites that allegedly aimed to wield power.

What does this tell us about right-wing populism's relationship to the truth? First of all, not all RWP ideas are founded on the same logic of truth-telling and verification. Although the de-legitimization of established truths is a central aspect of both politicians' and followers' discourse, RWP rhetoric has an adaptable and heterogenous perspective on the legitimization of convenient truths. We first of all find some support for Harambam and Aupers' (2015) interpretation: Populism does not always oppose scientific institutions and empirical evidence. However, RWP ideas can, under some conditions, and especially when considering the rhetoric of RWP supporters and Baudet in times of the pandemic, reject scientific techniques and contrast de-legitimized science to people-centric knowledge, gut feelings, and common sense. This reflects Saurette and Gunster's (2011) notion of "epistemological populism": The populist replacement of scientific principles with peoplecentric evidence and experiences. In populist constructions of the truth, an antagonism between the people's honesty and the elite's deception is often central-and connected to a conspiracy that stresses the intentional nature of the dishonest and hidden reality propagated by the elites (Mede \& Schäfer, 2020). In line with the principles of science-related populism (Mede \& Schäfer, 2020), the truth claims of elite actors were seen as biased and detached from the experiences and everyday lives of the ordinary people-which included references to popular sovereignty. The ordinary people should allegedly have the power to make legitimate truth claims. This construction of populist truths has an important moral component: The ordinary people and their everyday experiences were regarded as virtuous, whereas elite actors, scientists, and doctors were seen as unvirtuous. They allegedly deceived the ordinary people and deliberately misinformed them in order to cause harm and secure gains.

Based on our findings, we coin the idea of an "adaptable and relative construction of confirmation-biased truthfulness" central in RWP discourse. This concept acknowledges the flexible and chameleonic nature of populism (also see e.g., Mazzoleni, 2003) and the universal one-sided nature of the truth propagated in populist discourse (Waisbord, 2018). RWP rhetoric may use all sorts of truth claims as long as they consolidate the political agenda and reality of the communicator. Empirical evidence and expert knowledge are quoted, de-contextualized, and re-interpreted and used as a form of argumentation as long as such knowledge is congruent with the RWP agenda (i.e., to de-legitimize the political establishment). People-centric realities, gut feelings, common sense, and conspiracy theories are strategically used in the face of counter-attitudinal evidence. This relative and flexible understanding of populist truth claims helps us to explain the inconsistency of the role of facts, experts, and evidence in populist discourse.

Regarding the limitations and scope of our conclusions, some reflections need to be included here. First of all, we focused on a single country, two specific RWP leaders, and a biased selection of community pages. 
By focusing on a prototypical case of West-European right-wing populism, we believe that some of the main patterns of discourse identified here are transferrable to other European countries with successful RWP parties and similar contextual factors (i.e., moderate to high levels of distrust in mainstream media and the established political order). Hence, in other countries (i.e., Germany and France), de-legitimizing discourse and anti-media sentiments are also constantly expressed by RWP actors. In addition, overall trust levels in the mainstream media and political institutions are comparable in many European countries - which should also offer a favorable context for the relative construction of truth claims by politicians and their supporters. Yet, we suggest future research to pay more attention to regional differences and include most-different systems: Do left-wing populist actors make similar claims about (un)truthfulness, and do our findings hold in systems with either lower (i.e., the US, France, Hungary) or higher (i.e., Sweden, Norway) levels of media trust? In addition, although both Twitter and Facebook were included, there are other social media platforms and alternative media platforms that may offer a relevant context for the study of populist truth claims. To further explore the relevance of affordances that differ across platforms, future research may extend the analysis to different platforms, such as the more visually oriented platform Instagram.

Finally, there are some moral and ethical considerations connected to this study. The main researcher selected the online RWP communities based on prior experiences with these platforms - the selection is therefore biased and skewed by accessibility. Many RWP followers mobilize and communicate in private groups and closed communities that could not be accessed by this researcher. Even though RWP supporters are a difficult population to include directly in scientific research, future studies should try harder in involving their own experiences and make them an integral part of the analyses (i.e., individual interviews and focus groups).

Despite these limitations, this article has offered novel insights into how RWPs and their followers are empowered and platformed to share their antagonistic perspective on truthfulness via social media-hereby actively contributing to developments toward an increasingly more relative, debatable, and antagonistic understanding of politicized truths in a communication setting of high institutional distrust.

\section{Conflict of Interests}

The author declares no conflict of interests.

\section{References}

Aalberg, T., Esser, F., Reinemann, C., Strömbäck, J., \& de Vreese, C. H. (Eds.). (2017). Populist political communication in Europe. Routledge.

Brewer, S. (2011). Logocratic method and the analysis of arguments in evidence. Law, Probability and Risk, 10(3), 175-202. https://doi.org/10.1093/lpr/mgr013

Bucher, T., \& Helmond, A. (2018). The affordances of social media platforms. In J. Burgess, A. Marwick, \& T. Poell (Eds.), The SAGE handbook of social media (pp. 233-253). SAGE.

Busby, E. C., Gubler, J. R., \& Hawkins, K. (2019). Framing and blame attribution in populist rhetoric. The Journal of Politics, 81(2), 616-630. https://doi.org/ 10.1086/701832

Canovan, M. (1999). Trust the people! Populism and the two faces of democracy. Political Studies, 47, 2-16. https://doi.org/10.1111/1467-9248.00184

Egelhofer, J. L., \& Lecheler, S. (2019). Fake news as a two-dimensional phenomenon: A framework and research agenda. Annals of the International Communication Association, 43, 97-116. https://doi.org/ 10.1080/23808985.2019.1602782

Engesser, S., Ernst, N., Esser, F., \& Büchel, F. (2017). Populism and social media: How politicians spread a fragmented ideology. Information, Communication \& Society, 20(8), 1109-1126. https://doi.org/10.1080/ 1369118X.2016.1207697

Fawzi, N. (2019). Untrustworthy news and the media as "enemy of the people?" How a populist worldview shapes recipients' attitudes toward the media. International Journal of Press/Politics, 24(2), 146-164. https://doi.org/10.1177/1940161218811981

Gerbaudo, P. (2018). Social media and populism: An elective affinity? Media, Culture \& Society, 40(5), 745-753. https://doi.org/10.1177/0163443718772 192

Glaser, B., \& Strauss, A. (1967). The discovery of grounded theory. Aldine Publishing Company.

Groshek, J., \& Koc-Michalska, K. (2017). Helping populism win? Social media use, filter bubbles, and support for populist presidential candidates in the 2016 US election campaign. Information, Communication \& Society, 20(9), 1389-1407. https://doi.org/ 10.1080/1369118X.2017.1329334

Hameleers, M. (2020). Populist disinformation: Exploring intersections between online populism and disinformation in the US and the Netherlands. Politics and Governance, 8(1), 146-157. https://doi.org/ 10.17645/pag.v8i1.2478

Hameleers, M., Bos, L., \& de Vreese, C. H. (2017). They did it: The effects of emotionalized blame attribution in populist communication. Communication Research, 44(6), 870-900. https://doi.org/10.1177/ 0093650216644026

Hameleers, M., \& Minihold, S. (2021). Constructing discourses on (un)truthfulness: Attributions of reality, misinformation, and disinformation by politicians in a comparative social media setting. Communication Research. Advance online publication. https://doi. org/10.1177/0093650220982762

Harambam, J., \& Aupers, S. (2015). Contesting epistemic authority: Conspiracy theories on the bound- 
aries of science. Public Understanding of Science, 24(4), 466-480. https://doi.org/10.1177/096366251 4559891

Hopster, J. (2021). Mutual affordances: The dynamics between social media and populism. Media, Culture \& Society, 43(3), 551-560. https://doi.org/10.1177/ 0163443720957889

Jacobs, K., \& Spierings, N. (2019). A populist paradise? Examining populists' Twitter adoption and use. Information, Communication \& Society, 22(12), 1681-1696. https://doi.org/10.1080/1369118X. 2018.1449883

Jagers, J., \& Walgrave, S. (2007). Populism as political communication style: An empirical study of political parties' discourse in Belgium. European Journal of Political Research, 46(3), 319-345. https://doi.org/ 10.1111/j.1475-6765.2006.00690.x

Krämer, B., Fernholz, T., Husung, T., Meusel, J., \& Voll, M. (2021). Right-wing populism as a worldview and online practice: Social media communication by ordinary citizens between ideology and lifestyles. European Journal of Cultural and Political Sociology, 8(3), 235-264. https://doi.org/10.1080/ 23254823.2021.1908907

Lowry, P. B., Zhang, J., Wang, C., \& Siponen, M. (2016). Why do adults engage in cyberbullying on social media? An integration of online disinhibition and deindividuation effects with the social structure and social learning model. Information Systems Research, 27(4), 962-986. https://doi.org/10.1287/isre.2016. 0671

Mazzoleni, G. (2003). The media and the growth of neopopulism in contemporary democracies. In G. Mazzoleni, J. Stewart, \& B. Horsfield (Eds.), The media and neo-populism: A contemporary comparative analysis (pp. 1-20). Praeger.

Mede, N. G., \& Schäfer, M. S. (2020). Science-related populism: Conceptualizing populist demands toward science. Public Understanding of science, 29(5), 473-491. https://doi.org/10.1177/0963662520924 259

Mudde, C. (2004). The populist zeitgeist. Government and Opposition, 39(4), 542-564. https://doi.org/ 10.1111/j.1477-7053.2004.00135.x

Oliveira, T., Evangelista, S., Alves, M., \& Quinan, R. (2021). "Those on the right take chloroquine": The illiberal instrumentalization of scientific debates during the Covid-19 pandemic in Brasil. Javnost-The Public,
28(2), 165-184. https://doi.org/10.1080/13183222. 2021.1921521

Rooduijn, M., Van Kessel, S., Froio, C., Pirro, A., De Lange, S., Halikiopoulou, D., Lewis, P., Mudde, C., \& Taggart, P. (2019). Home. The PopuList. https://popu-list.org

Saurette, P., \& Gunster, S. (2011). Ears wide shut: Epistemological populism, argutainment and Canadian conservative talk radio. Canadian Journal of Political Science, 44(1), 195-218. https://doi.org/10.1017/ S0008423910001095

Schulz, A., Wirth, W., \& Müller, P. (2020). We are the people and you are fake news: A social identity approach to populist citizens' false consensus and hostile media perceptions. Communication Research, 47(2), 201-226. https://doi.org/10.1177/ 0093650218794854

Suldovsky, B., Landrum, A., \& Stroud, N. J. (2019). Public perceptions of who counts as a scientist for controversial science. Public Understanding of Science, 28(7), 797-811. https://doi.org/10.1177/ 0963662519856768

Valenzuela, S., Correa, T., \& Gil de Zúñiga, H. (2018). Ties, likes, and tweets: Using strong and weak ties to explain differences in protest participation across Facebook and Twitter use. Political Communication, 35(1), 117-134. https://doi.org/10.1080/10584609. 2017.1334726

Van Dijk, T. A. (1993). Principles of critical discourse analysis. Discourse \& Society, 4(2), 249-283. https://doi. org/10.1177/0957926593004002006

Vraga, E. K., \& Bode, L. (2020). Defining misinformation and understanding its bounded nature: Using expertise and evidence for describing misinformation. Political Communication, 37(1), 136-144. https://doi. org/10.1080/10584609.2020.1716500

Waisbord, S. (2018). The elective affinity between posttruth communication and populist politics. Communication Research and Practice, 4, 17-34. https://doi. org/10.1080/22041451.2018.1428928

West, E., \& Iyengar, S. (2020). Partisanship as a social Identity: Implications for polarization. Political Behavior. Advance online publication. https://doi.org/ 10.1007/s11109-020-09637-y

Ylä-Anttila, T. (2018). Populist knowledge: "Post-truth" repertoires of contesting epistemic authorities. European Journal of Cultural and Political Sociology, 5(4), 356-388.

\section{About the Author}

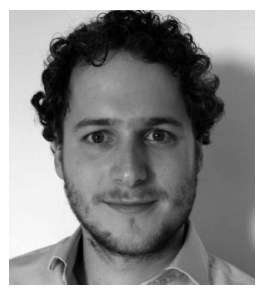

Michael Hameleers (PhD, University of Amsterdam) is assistant professor in political communication at the Amsterdam School of Communication Research (ASCoR), Amsterdam, The Netherlands. His research interests include populism, framing, (affective) polarization, and disinformation. 